\title{
A Case of Primary Tuberculosis of the Lacrimal Sac Presenting as Epiphora
}

\author{
Sang Yun Lee ${ }^{1}$, Sangwook Park ${ }^{1}$, Jong-Sil Lee ${ }^{2}$, and Yung Jin Jeon ${ }^{1}$ (D) \\ ${ }^{1}$ Department of Otorhinolaryngology, Gyeongsang National University Hospital, Jinju; and \\ ${ }^{2}$ Department of Pathology, Gyeongsang National University School of Medicine, Jinju, Korea
}

\author{
유루로 내원한 원발성 눈물주머니 결핵 1 예 \\ 이상윤 ${ }^{1} \cdot$ 박상욱 $^{1} \cdot$ 이종실 $^{2} \cdot$ 전영진 $^{1}$ \\ 경상대학교병원 이비인후과, ${ }^{1}$ 경상대학교 의과대학 병리학교실 ${ }^{2}$
}

\author{
Received March 19, 2020 \\ Revised May 21, 2020 \\ Accepted May 28, 2020 \\ Address for correspondence \\ Yung Jin Jeon, MD \\ Department of Otorhinolaryngology, \\ Gyeongsang National \\ University Hospital, \\ 79 Gangnam-ro, \\ Jinju 52727, Korea \\ Tel $+82-55-750-8178$ \\ Fax $+82-55-759-0613$ \\ E-mail myjin8704@gmail.com
}

Extra-pulmonary tuberculosis usually progresses as a secondary infection from pulmonary tuberculosis, and tuberculosis of the head and neck region. Tuberculosis of ocular and periocular areas, however, is a rare disease. Among ocular tuberculosis involving the adnexal structures, a few lacrimal sac tuberculosis has been reported. We recently experienced a case of lacrimal sac tuberculosis presenting as epiphora. Examination revealed bilateral nasolacrimal duct obstruction and the patient underwent endoscopic endonasal dacryocystorhinostomy. During the operation, a biopsy taken from the unhealthy looking lacrimal sac filled with caseous necrotic tissue was suggestive of tuberculosis. Histopathological features and further systemic evaluation confirmed tuberculosis. She was treated medically with anti-tubercular agents. The new opening of the lacrimal sac was patent and epiphora was resolved successfully at a year follow up. This report highlights the requirement of high suspicion of tuberculosis, even in the nasolacrimal drainage system. Korean J Otorhinolaryngol-Head Neck Surg 2021;64(3):202-6

Key Words Dacryocystorhinostomy $\cdot$ Epiphora $\cdot$ Lacrimal sac $\cdot$ Nasolacrimal duct Tuberculosis.

\section{서 론}

한국은 $\mathrm{OECD}$ 회원 35 개국 중 결핵 발생률 1 위로, 특히 65 세 이상의 노인 결핵 유병률은 후진국 수준으로 심각하다. ${ }^{1)}$ 폐외(extra-pulmonary)결핵은 대부분 폐결핵이 선행하지만 폐결핵 없이 15 20\%에서는 원발성으로 발생하기도 한다. ${ }^{2}$ 폐외결핵 중에서도 2 10\% 이내로 두경부 영역에서 발견되 고, ${ }^{3,4}$ 두경부 결핵 중에서도 안구 또는 안와 결핵은 매우 드 문 질환이며 국내 학술지에는 눈물주머니(lacrimal sac)를 침 범한 결핵에 대해서는 아직 보고된 바가 없다. 눈물주머니 결 핵은 대개 일반적인 만성 눈물주머니염과 비슷한 임상 증상

This is an Open Access article distributed under the terms of the Creative Commons Attribution Non-Commercial License (https://creativecommons.org/licenses/by-nc/4.0) which permits unrestricted non-commercial use, distribution, and reproduction in any medium, provided the original work is properly cited.
으로 진단이 지연되기 쉽다. 한편 코눈물관 폐쇄의 수술적 치 료에 있어 안과 의사들이 외부 접근법으로 누낭비강문합술 을 해왔지만 내시경적 비강 내 누낭비강문합술(endoscopic endonasal dacryocystorhinostomy)의 치료 결과가 우수하 여, 비강의 해부학과 비내 내시경 수술에 익숙한 이비인후과 의사들이 시행하며 영역이 확장하고 있다.5) 최근 저자들은 유 루(epiphora)를 주소로 내원하여 내시경적 비강 내 누낭비강 문합술 중 눈물주머니 결핵으로 진단되어 성공적으로 치료 한 증례를 경험하였기에 문헌 고찰과 함께 보고하고자 한다.

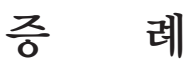

53 세 여자 환자로 1 년 전부터 시작된 양측 유루증 및 1 개월 전부터 반복되는 우안 눈꺼풀의 발적과 부종으로 내원하였다 
(Fig 1A). 비강이나 호흡기 증상을 호소하지 않았고 가족력 이나 과거력상 특이 사항은 없었다. 이학적 검진이나 이비인후 과 비내시경 검사에서는 비중격 만곡증 등의 이상 소견을 발 견하지 못하였다(Fig. $1 \mathrm{~B}$ ). 안과 검진상 시력은 우안 1.0 , 좌안 0.8 이었고, 안압은 양안 $16 \mathrm{~mm} \mathrm{Hg}$ 으로 측정되었다. 안구 운 동 및 시야의 제한은 없었고 안저 검사는 정상이었다. 세극등 검 사에서 우측 상, 하 눈물점의 발적과 부종이 관찰되었다. 양
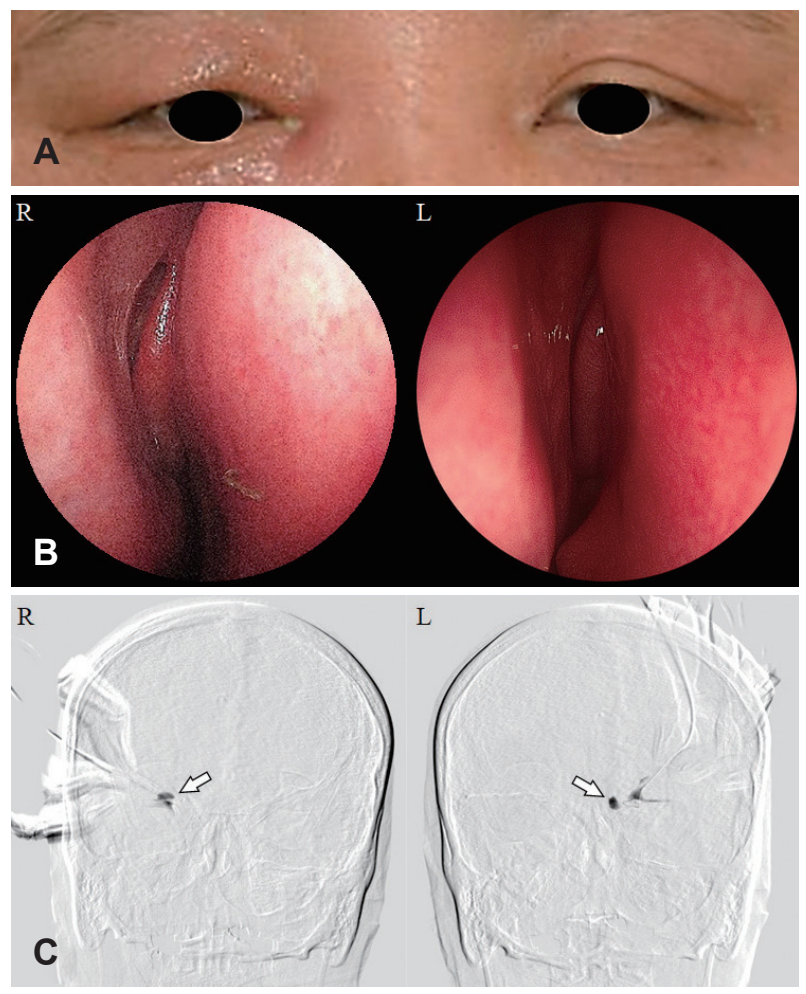

Fig. 1. Preoperative evaluations. The medical photography shows the right eyelid swelling $(A)$. The endoscopic view of both nasal cavities shows the healthy mucosa (B). Dacryocystography demonstrates the bilateral nasolacrimal drainage obstruction (C, arrows).
측 눈물점(lacrimal punctum)에 식염수를 주입하여 콧속으 로 배액 되지 않는 것을 확인하였고, 눈물주머니조영술(dacryocystography)에서 양측 눈물주머니의 조영제 충만(contrast filling)과 코눈물관으로 조영제 통과(contrast passage) 가 관찰되지 않았다(Fig. $1 \mathrm{C}$ ). 안와 전산화단층촬영 검사에 서 양측 코눈물관이 늘어나 있고(Fig. 2A), 우측 내안각(medial canthus)의 하측으로 약 $1.7 \mathrm{~cm}$ 가량의 연조직 음영이 관 찰되었으나 안와골 침식 등의 소견은 없었다(Fig. $2 \mathrm{~B}$ and $\mathrm{C}$ ). 우측 만성 눈물주머니염을 동반한 양측 코눈물관 폐쇄 진단 하에 전신 마취 하 양측 내시경적 비강 내 누낭비강문합술을 계획하였다. 수술 중 중비갑개를 안쪽으로 젖히고 더듬자를 통과시켰을 때 좌측에 비해 우측에서 눈물소관 내로 연조직 에 의한 저항이 느껴졌다. 또한 통과된 더듬자 주변으로 수 술 전에 발견하지 못했던 염증성 비강 점막 병변이 관찰되었 고(Fig. 3A), 우측 눈물소관을 통해 식염수를 통과시켰을 때 비강 내로 치즈 질감의 분비물이 밀려나왔다(Fig. 3B). 눈물 주머니 점막의 조직병리학적 검사 소견상 만성 육아종성 염 증(chronic granulomatous inflammation)과 건락 괴사(caseous necrosis)가 관찰되었고(Fig. 3C), 항산균 도말 검사와 결핵균 핵산증폭검사 모두 음성이었다. 결핵 의심 하에 호흡 기내과로 의뢰되었고 흥부 $\mathrm{X}$ 선 검사는 정상이었지만 흥부 전 산화단층촬영 검사에서 우측 단일 폐결절이 관찰되었다(Fig. $4 \mathrm{~A})$. 객담 항산균 도말 검사와 결핵균 핵산증폭검사 모두 음 성이었다. 대한결핵 및 호흡기학회의 결핵 진료 지침에 따라 조직검사, 흉부 전산화단층촬영 검사 등 임상적으로 활동성 도말 음성 결핵으로 진단하여 총 6개월간 항결핵제 치료를 하였다. 치료 종료 후 흥부 전산화단층촬영 검사에서 기존의 폐결절이 없어졌고(Fig. 4B), 술후 1 년째 비내시경 검사에서 눈물주머니의 새로운 개방창이 잘 유지되어(Fig. $4 \mathrm{C})$, 유루증
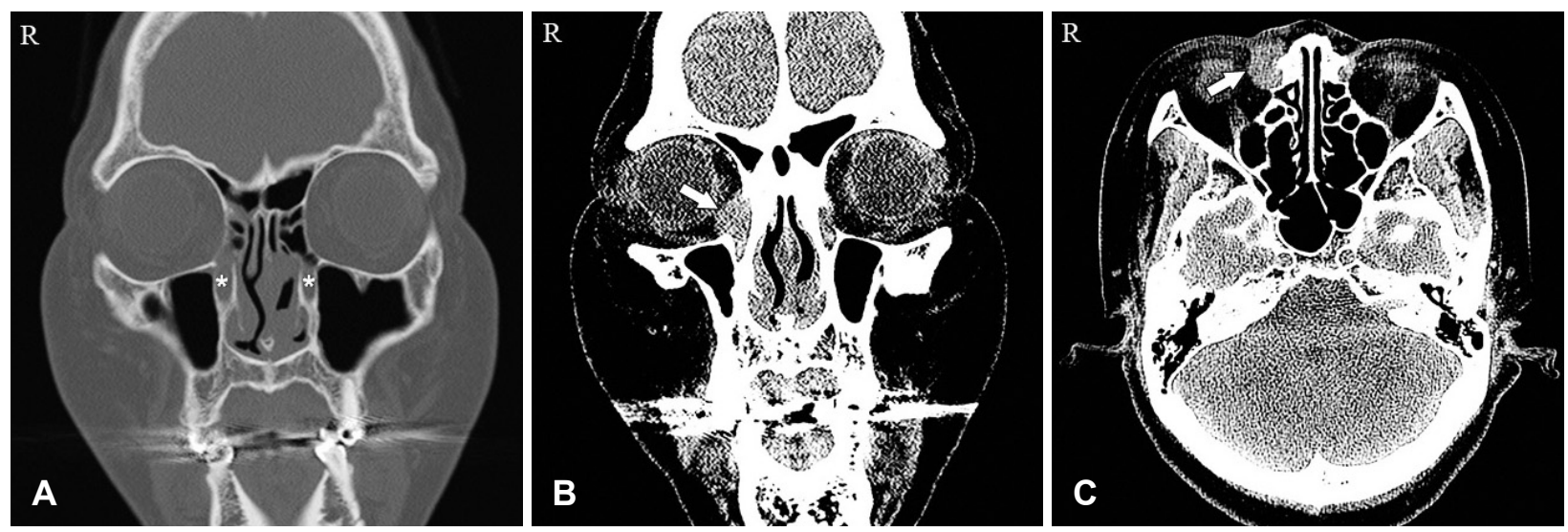

Fig. 2. Preoperative radiographic examinations. Non-enhanced orbit CT shows dilated bilateral nasolacrimal ducts (A: bone window setting, asterisk), and soft tissue densities around right inferior medial canthus and lacrimal sac (B: coronal image; C: axial image, soft tissue window setting; arrow). 
재발이나 특이 소견 없이 외래 추적 관찰 중이다.

\section{고 찰}

마이코박테리아(mycobacteria)의 원발 감염 부위는 폐 조
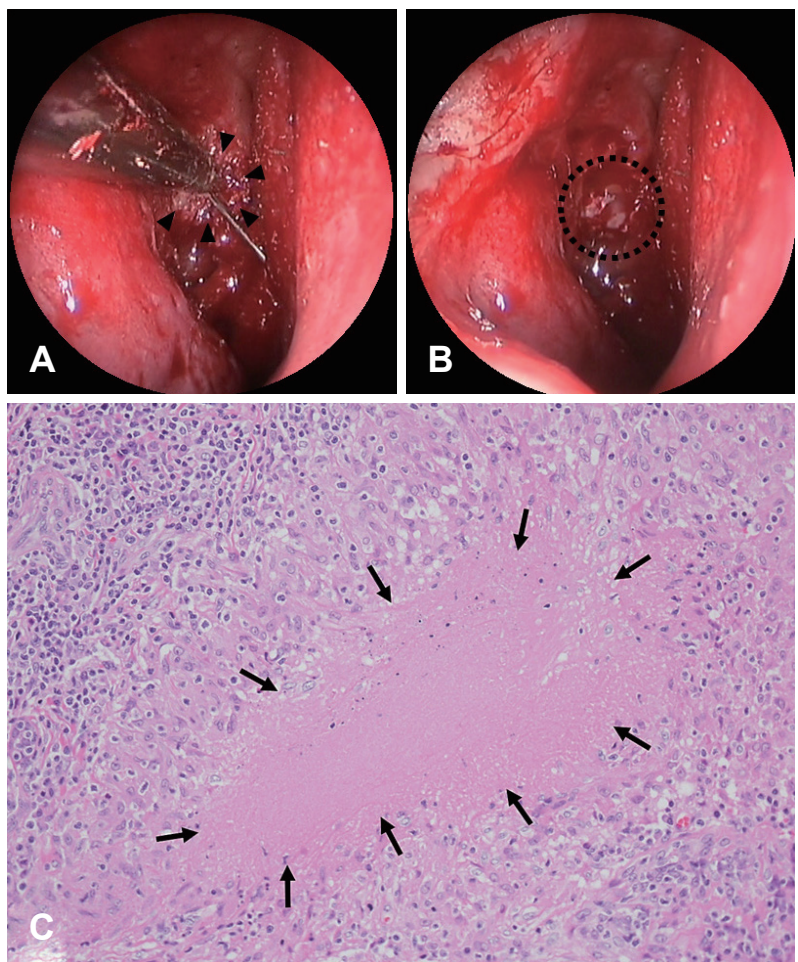

Fig. 3. Intraoperative endoscopic findings of right endoscopic endonasal dacryocystorhinostomy show inflammatory mucosa around the tip of Bowman's canalicular probe after exposure of the nasolacrimal sac ( $A$, arrowheads), and granulomatous necrotic discharge during saline irrigation through inferior punctum ( $B$, dotted circle). The histopathological finding of nasal tissue biopsy shows caseous necrosis surrounded by inflammatory cells (C: H\&E stain, $\times 400$; arrows). H\&E stain: hematoxylin and eosin staining.
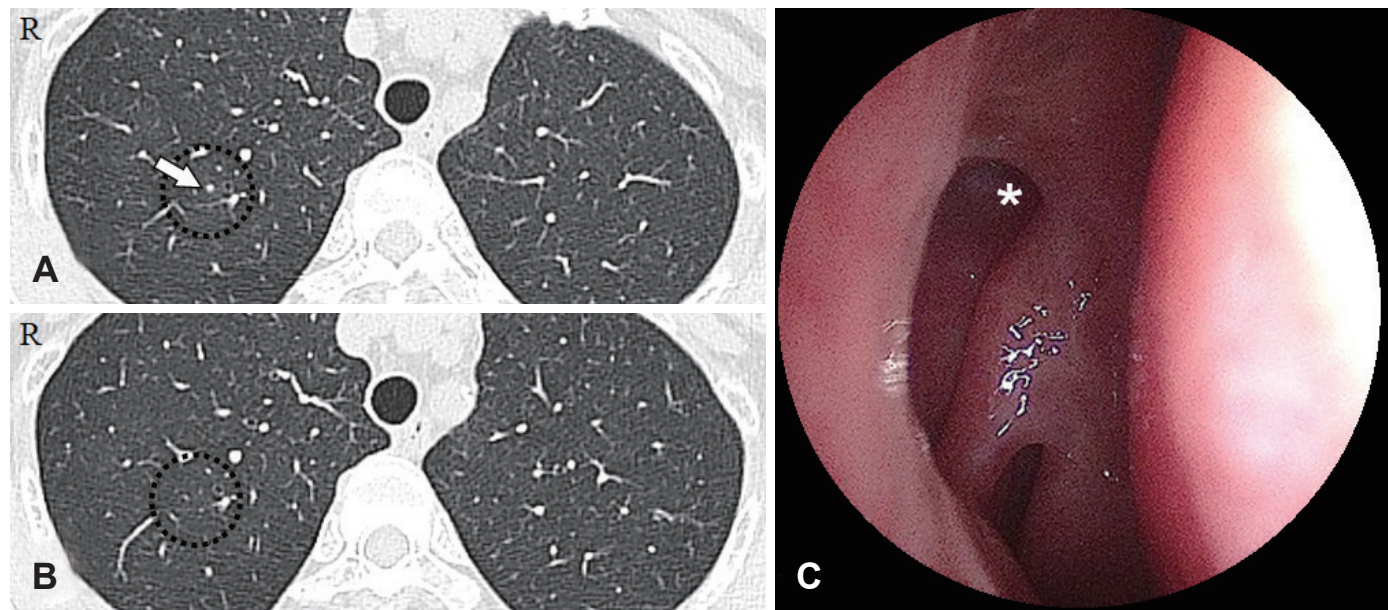

Fig. 4. Non-enhanced chest CT findings. An inflammatory lung nodule was found preoperatively ( $A$, arrow), the lung nodule showed interval regression 6 months after anti-tuberculosis agent medication ( $B$, dotted circle). The endoscopic view of the right nasal cavity shows a new opening of the nasolacrimal drainage system (asterisk) and good postoperative results 1 year after the operation. 
결핵은 림프혈행성 전파-(lymphohematogenous dissemination)를 통해 거의 모든 장기에 감염시킬 가능성이 있고 비 특이적으로 다양한 임상 증상으로 인해 진단이 지연될 수 있 다. ${ }^{10)}$ 특히 폐결핵이 없는 경우 국소 증상을 호소하는 경우가 더 많기 때문에 증상만으로는 결핵을 의심하기가 쉽지 않 다. 눈물주머니 결핵의 주요 임상 증상은 본 증례처럼 유루증 과 내안각 부종으로 알려져 있다. ${ }^{2)}$ 통상적인 눈물주머니염도 눈물주머니의 비대 및 염증 소견과 함께 눈꺼풀의 발적과 부 종, 기계적 눈꺼풀 처짐 및 결막 충혈 및 부종, 눈물샘 촉진 시 압통, 드물게 안구 통증과 복시 등으로 알려져 있다. ${ }^{11)}$

안와 전산화단층촬영은 비부비동이나 안구 또는 눈물주머 니오목(lacrimal sac fossa)의 병변을 평가하는 데 도움을 줄 수 있다. 대개 안구 돌출과 시력 감소는 없으며 이환된 눈물 주머니의 비대와 함께 테논낭(tenon's capsule), 외직근(lateral rectus muscle) 등의 주위 구조물에 염증이 침범된 소견을 보이며 안와골은 침범하지 않는다. ${ }^{12)}$ 본 증례에서처럼 내안각 주위로 연조직 음영을 감지할 수 있었지만 뚜렷한 눈물주머 니오목의 골침식 또는 골수 변화를 관찰할 수는 없었다. 눈 물주머니염과 달리 눈물주머니 종양은 눈물주머니오목의 골 침식을 나타낼 수 있고, 의심되면 조영 증강 자기공명영상촬 영 검사가 연조직 병변의 감별 진단에 도움이 될 수 있겠다. 하 지만 눈물눈물주머니 종양은 대개 영상 검사만으로 만성 눈 물주머니염과 감별하기 어렵고 대부분 코눈물관 폐쇄에 의한 누낭비강문합술 중에 우연히 발견된다고 보고된다. ${ }^{13)}$ 한편 영 상의학적 흥부 검사로 폐결핵 동반 여부를 평가하기 위해 흥 부 X선 촬영이 중요할 것이다.

눈물주머니 결핵 등의 두경부에서 발견되는 결핵의 경우 육 안으로는 감별 진단하는 것이 실제적으로 어렵고 조직검사, 균체 도말 또는 혈청 검사 등에 의존해야 한다. 하지만 결핵균 수가 폐결핵에 비해 비교적 적어서 분비물에서 항산균 도말 이나 배양 검사로는 결핵균을 증명할 확률이 낮다. ${ }^{14)}$ 따라서 수술 전 또는 수술 중 육아종성 병변이나 골침식이나 치즈 질감의 분비물이 관찰된다면 조직검사와 결핵균 핵산증폭검 사 등이 필요하다. 조직검사를 의뢰할 때에도 검체를 포르말 린에 보관하면 결핵균이 파괴될 수 있기 때문에 멸균 생리식 염수에 담아 조직 배양을 의뢰할 것을 권고한다. ${ }^{15)}$ 결핵 확진 을 위해서는 균 배양이 표준 검사(gold standard) 방법이지만 본 증례처럼 항산균 도말이 음성이면서 결핵균 핵산증폭검 사가 음성인 경우에도 환자의 임상 증상 또는 방사선학적 소 견에서 결핵이 의심되고, 항결핵 효과가 없는 광범위 항생제 치료에 반응이 없는 경우 배양 음성 결핵이라고 정의할 수 있 다.) 결핵 치료로 임상 증상 및 방사선학적 소견이 호전을 보 이면 임상적으로 판단하여 배양 음성 결핵으로 최종적으로
진단할 수 있다.

특징적인 결핵의 조직병리학적인 소견은 중심부 건락 괴사 를 동반한 육아종 염증이다. ${ }^{16)}$ 조직학적으로 육아종은 감염 또는 이물질(foreign body)에 대한 염증 반응에 의해 발생한 대식세포(macrophage)의 조직화된 집합체(organised collection)로 정의된다. 정상적인 상처 치유 중에 발생하는 신생 혈관 조직인 육아 조직(granulation tissue)과는 구별되어야 한다. 결핵균(tubercle bacilli)에 의해 형성된 육아종은 더 많 은 수의 거대세포(giant cell)와 상피모양 세포(epithelioid cell)가 관찰되는 경향이 있다. 환자의 면역 기능이 저하되어 있으면 화농성 반응이 많아지고 육아종이 잘 형성되지 않을 수 있기 때문에 전형적인 중심부 건락 괴사를 동반한 육아종 이 관찰되지 않더라도 결핵을 완전히 배제할 수는 없다.

폐외결핵의 치료 원칙은 폐결핵과 같고, 경우에 따라 수술 적 중재가 필요할 수 있다. 눈문주머니 결핵의 치료는 누낭비 강문합술 등의 코눈물관 폐쇄를 해결하기 위한 수술적인 치 료와 항결핵제 복합 투여를 고려해야겠다. 항결핵제 투여는 세균학적 또는 임상적으로 결핵으로 진단된 환자에게서 시작 하게 되는데 초치료는 2 개월의 초기 집중 치료기와 4 개월의 후기 유지 치료기로 구분되어 이소니아지드, 리팜핀, 에탐부 톨, 피라진아미(HREZ)를 동시에 복용하여 신속한 균 음전을 목표로 하고, 이소니아지드, 리팜핀, 에탐부톨(HRE)을 동시 에 복용하여 재발을 예방한다.) 대부분의 경우 완치가 되지만 폐외결핵의 치료 경과에 대한 평가도 균 배양 등의 미생물학 적 증거보다는 임상 증상의 호전 여부와 영상의학적 소견 변 화에 근거하여 판단해야 하는 어려움이 있다. ${ }^{15}$

코눈물관 폐쇄에 의한 유루증 치료가 내시경적 비강 내 접 근법으로 우수한 치료 결과를 보여 안과 의사들도 외부 접근 법보다 선호하며 이비인후과 의사들의 영역으로도 확장되고 있다. 이에 저자들은 본 증례와 문헌 고찰을 통해 눈물주머니 결핵의 경우 높은 확률로 비강 결핵을 동반할 수 있기 때문에 유루증으로 내원한 환자에 있어 비강 증상이 없더라도 비내시 경 검사를 통한 점막 병변에 대한 면밀한 관찰이 필요하고, 수 술 전 전산화단층촬영 검사를 통한 눈물주머니를 포함한 코눈 물관 계통을 평가가 중요하며, 수술 중 육아종성 결핵 병변이 의심되면 조직검사를 통해 조기 진단과 신속한 항결핵제 요법 을 병행하여 좋은 치료 결과를 경험하였기에 보고하는 바이다.

\section{Acknowledgments}

This work was supported by the Basic Science Research Program through the National Research Foundation of Korea (NRF), funded by the Ministry of Education (grant number 2019R1C1C1002064 to YJJ). 


\section{Author Contribution}

Conceptualization: Sang Yun Lee, Yung Jin Jeon. Data curation: Sangwook Park, Jong-Sil Lee. Funding acquisition: Yung Jin Jeon. Investigation: Sang Yun Lee, Sangwook Park. Supervision: Yung Jin Jeon. Validation: Jong-Sil Lee, Yung Jin Jeon. Writing — original draft: Sang Yun Lee, Yung Jin Jeon. Writing — review \& editing: Yung Jin Jeon.

\section{ORCID}

Yung Jin Jeon

https://orcid.org/0000-0002-0285-5534

\section{REFERENCES}

1) Go U, Park M, Kim UN, Lee S, Han S, Lee J, et al. Tuberculosis prevention and care in Korea: Evolution of policy and practice. $\mathrm{J}$ Clin Tuberc Other Mycobact Dis 2018;11:28-36.

2) Sagar P, Shankar R, Wadhwa V, Singh I, Khurana N. Primary tubercular dacryocystitis - a case report and review of 18 cases from the literature. Orbit 2019;38(4):331-4.

3) Prasad KC, Sreedharan S, Chakravarthy Y, Prasad SC. Tuberculosis in the head and neck: Experience in India. J Laryngol Otol 2007;121(10): 979-85.

4) Khan S, Pujani M, Jetley S. Primary Nasal Tuberculosis: Resurgence or coincidence - a report of four cases with review of literature. $\mathrm{J}$ Lab Physicians 2017;9(1):26-30.

5) Chung YJ. Management of nasolacrimal duct obstruction: ENT Surgeon's perspective. Korean J Otorhinolaryngol-Head Neck Surg 2017;60(10):481-90.
6) Al-Serhani AM. Mycobacterial infection of the head and neck: Presentation and diagnosis. Laryngoscope 2001;111(11 Pt 1):2012-6.

7) Lee SH. Diagnosis and treatment of latent tuberculosis infection: The updated 2017 Korean guidelines. Korean J Med 2018;93(6):50917.

8) Konstam PG, Meynell MJ. Tuberculosis of the nasolacrimal duct. Lancet 1951;1(6652):443-4.

9) Babu K, Mukhopadhyay M, Bhat SS, Chinmayee J. Orbital and adnexal tuberculosis: A case series from a South Indian population. J Ophthalmic Inflamm Infect 2014;4:12.

10) Gupta N, Janaki RV, Ali MJ. Primary nasal tuberculosis with lacrimal drainage involvement. Int J Pediatr Otorhinolaryngol Extra 2017;17:1-3

11) Yum HR, Kang NY. Idiopathic orbital inflammation presenting as unilateral dacryoadenitis in a child. J Korean Ophthalmol Soc 2011; 52(11):1357-61.

12) Cho YS, Choi N, Kim HY. A two cases of primary tuberculosis at the nasopharynx. J Rhinol 2015;22(2):123-7.

13) Kang B, Jung H, Shin JM, Park IH, Lee HM. Clinical characteristics of lacrimal sac tumors: Report of ten cases. J Rhinol 2017;24(1):14-9.

14) Kim TS, Park SK, Park CK. Four cases of primary tuberculosis of the nasal cavity. Korean J Otolaryngol 1999;42(5):656-9.

15) Golden MP, Vikram HR. Extrapulmonary tuberculosis: An overview. Am Fam Physician 2005;72(9):1761-8.

16) Masterson L, Srouji I, Kent R, Bath AP. Nasal tuberculosis--an update of current clinical and laboratory investigation. J Laryngol Otol 2011;125(2):210-3. 